\title{
NILAI-NILAI PENDIDIKAN KARAKTER PADA MAKNA LUKISAN PETRUK DADI RATU, SEMARE KALING-KALINGAN MEGA KARYA SUBANDI GIYANTO
}

\author{
Hanung Bramantyo Yuniawan dan Marzuki \\ Pascasarjana Universitas Negeri Yogyakarta \\ h.yuniawan@gmail.com; mazuki@uny.ac.id
}

\begin{abstract}
Abstrak: Wayang yang merupakan salah satu kekayaan intelektual menyatu dan menjadi bagian dari kehidupan masyarakat Jawa. Wayang juga menjadi sumber inspirasi sehingga masyarakat mengapresiasinya dalam bentuk lukisan wayang Penelitian ini bertujuan untuk mendeskripsikan makna lukisan wayang karya Subandi Giyanto berjudul Petruk Dadi Ratu, Semare Kaling-Kalingan Mega terkait dengan pendidikan karakter. Penelitian ini merupakan penelitian kualitatif. Interpretasi data menggunakan metode semiotika Pierce. Objek material penelitian yaitu lukisan Petruk Dadi Ratu, Semare Kaling-Kalingan Mega. Objek formalnya berupa makna simbolik dan pendidikan karakter. Data penelitian diperoleh dengan teknik observasi, wawancara, dan dokumentasi. Analisis data menggunakan teknik interaktif model Miles dan Huberman. Hasil penelitian menunjukkan bentuk lukisan yang menghadirkan Petruk sebagai subjek utama yang dikelilingi figur Petruk, Gareng, Togog, Bilung, Semar, Emban Ayu, dan Bagong yang memperlihatkan ketidakadilan, suap-menyuap, korupsi, kemiskinan, dan pencitraan serta objek-objek wuku Pahang. Selain itu dalam lukisan terdapat awan berkepala Sengkuni yang menutup beberapa objek termasuk menutup kepala Semar. Makna lukisan menggambarkan negara Petruk yang terlihat baik namun banyak kesedihan di dalamnya, karena kondisi sosial yang kacau termasuk diam dan dilupakannya sang pamomong. Nilai-nilai pendidikan karakter yang ada pada makna lukisan yaitu integritas, nasionalis, dan mandiri.
\end{abstract}

Kata kunci: lukisan wayang, makna simbolik, nilai-nilai pendidikan karakter.

\section{CHARACTER EDUCATION VALUES IN THE MEANINGS OF PETRUK DADI RATU, SEMARE KALING-KALINGAN MEGA PAINTING BY SUBANDI GIYANTO}

Abstract: Puppet that is one of the intellectual property and has become a part of the Javanese society life. Puppet is also a source of inspiration so that people appreciate it in the form of puppet paintings. This research aimed to describe the meaning of puppet painting by Subandi Giyanto entitled Petruk Dadi Ratu, Semare Kaling-Kalingan Mega related to character education. This was a qualitative research. Data interpretation used Pierce's semiotics method. The material object of research was the painting entitled Petruk Dadi Ratu, Semare Kaling-Kalingan Mega. The formal objects were symbolic meanings and character education. The data were obtained by observation, interview, and documentation techniques. Data analysis used interactive technique of the Miles and Huberman model. The results showed that the form of paintings presented Petruk as the main subject surrounded by figures of Petruk, Gareng, Togog, 
Bilung, Semar, Emban Ayu, and Bagong which showed injustice, bribery, corruption, poverty, imaging, and objects of wuku Pahang. In addition, there was a Sengkuni-headed cloud that covered several objects including covering Semar's head. The meaning of the painting was to reflect the state of Petruk that looks good but full of sadness due to chaotic social problems including silence and the forgotten pamomong (caregiver). The values of character education that exist in the meaning of painting was integrity, nationality, and independently.

Keywords: Puppet painting, symbolic meaning, character education values

\section{PENDAHULUAN}

Pendidikan merupakan upaya

untuk memerdekakan manusia. Memerdekakan di sini berarti menuntun segala potensi yang ada pada anak supaya anak dapat mencapai keselamatan dan kebahagiaan yang setinggi-tingginya sebagai manusia dan sebagai anggota masyarakat (Dewantara, 2011: 20). Salah satu yang menjadi tuntutan manusia merdeka adalah manusia yang berbudi baik. Pada kenyataannya tidak semua orang mempunyai budi pekerti seperti itu. Untuk itulah pendidikan karakter menjadi penting, karena dapat menjadikan manusia memperoleh kemerdekaannya dan berbudi baik.

Sikap manusia selalu berubah-ubah dan dipengaruhi oleh lingkungannya. Munculnya globalisasi dan semakin mudahnya manusia mengakses segala informasi tanpa kecuali juga turut andil bagian dalam mengubah cara hidup manusia. Melalui komunikasi antardaerah dan antarnegara, manusia saling bertukar kebudayannya. Akibatnya, kebudayaan yang lebih populer akan mendominasi. Semakin banyak kebudayaan populer yang masuk ke Indonesia, semakin ditinggalkannya kebudayaan asli yang berdampak pada berkurangnya sikap ketimuran yang lebih adiluhung, beradatistiadat, dan bertata krama dengan segala unggah-ungguhnya oleh masyarakat Indonesia. Sifat individualistis, lupa budaya sendiri, tawuran, geng motor, narkoba dan minuman keras, kurang menghargai perbedaan, berkurangnya rasa hormat pada orang tua, isu-isu negatif SARA (suku, agama, ras, dan antargolongan), hamil di luar nikah, kurangnya sopan santun, korupsi, klitih (pembacokan oleh orang tidak dikenal), produksi berita hoax, dan lain sebagainya menjadi hal lumrah yang sering ditemui (Rofiqah \& Sitepu, 2019; Irmayani, 2018; Juditha, 2018; Qolbiyyah, 2017; Rahadi, 2017; Setiawan, 2017).

Perilaku-perilaku negatif atau menyimpang diindikasikan sebagai hilangnya nilai karakter seseorang. Sedangkan sekolah yang harusnya ikut berperan dalam pembentukan karakter siswa malah lebih berfokus pada kecerdasan kognitif saja. Berdasarkan kesadaran tersebut, pendidikan karakter mulai dipertanyakan kembali. Di sekolah, pendidikan karakter yang terdapat dalam seni tradisi diajarkan kembali melalui pendidikan seni (seni budaya) sebagai pokok bahasan yang membawa nilai-nilai tradisi dan pendidikan karakter pada siswa. Wayang menjadi salah satu pokok 
bahasannya. Pesan-pesan kebaikan yang dibawakan tokoh-tokoh wayang diharapkan dapat mempengaruhi sikap siswa pada kehidupannya.

Bagi masyarakat Jawa, wayang bukan hanya sekedar tontonan namun juga tuntunan. Wayang sudah menyatu dan menjadi bagian dari kehidupan masyarakat dan sebagai salah satu kekayaan intelektual (Setyawan, 2020; Octavia \& Ismail, 2018). Wayang menjadi sumber inspirasi masyarakat salah satunya dalam bentuk lukisan wayang. Lukisan yang menggunakan wayang sebagai objek lukisannya. Untuk mendukung pendidikan di Indonesia pada bidang kesenian dilakukan kajian tentang lukisan wayang. Lukisan wayang dipilih karena selain menggunakan seni tradisi (wayang) sebagai subjeknya, lukisan menjadi barang seni yang populer keberadaannya. Seorang seniman yang menggunakan idiom wayang pada lukisannya adalah Subandi Giyanto.

Subandi Giyanto merupakan salah satu pelukis yang tinggal dan berkarya di Yogyakarta. Karyakaryanya mengolah figur-figur wayang purwa gaya Yogyakarta tanpa meninggalkan pakem wayang tersebut. Visualnya yang unik, yakni menggunakan figur wayang dengan konsep yang kekinian, kritis, kadang berbau satire, serta tradisional, tetapi tidak kuno dan ketinggalan zaman. Dari karya-karya lukisannya ini bisa jadi Subanti tidak lagi memosisikan figur-figur wayangnya sebagai bagian dari tradisi, tetapi membawa figur-figur wayang untuk lepas menjadi representasi manusiamanusia modern.
Untuk mengungkapkan ideidenya, Subandi banyak menggunakan tokoh Punakawan dan tokoh raksasa. Pada kajian ini dipilih satu lukisan Subandi Giyanto berjudul Petruk Dadi Ratu, Semare Kaling-Kalingan Mega. Pada lukisan ini, Subandi banyak menggunakan warna-warna terang dan saling kontras. Berbeda dengan lukisanlukisan sebelumnya, lukisan Petruk Dadi Ratu, Semare Kaling-Kalingan Mega tidak menampilkan visual wayang beber sebagai latar belakang. Selain figur tunggal Petruk terdapat objek-objek yang berukuran kecil yang tersebar memenuhi lukisan dan memiliki karakter saling kuat. Pada lukisan ini sosok Petruk berpenampilan sebagai seorang raja (Ratu). Pada kisah pewayangan, Petruk Dadi Ratu menceritakan Petruk sebagai rakyat biasa menjadi seorang Raja yang kemudian berakhir sebagai kekacauan atau ketidakmampuan seorang pemimpin. Kekecewaan rakyat pada pemimpin mengakibatkan krisis kepercayaan dan menimbulkan kekacauan di negaranya. Melalui kajian terhadap karya tersebut, dapat digali nilai-nilai pendidikan karakter.

Sudah ada beberaka kajian tentang wayang dengan berbagai lakonnya melalui berbagai pespektif yang berbeda-beda, khususnya terkait dengan pendidikan karakter (Setyawan, 2020; Whinarno \& Arifin, 2019; Arisyanto, Cahyono, \& Hartono, 2017). Namun, tidak banyak peneliti yang tertarik untuk mengkaji lakon yang terkait dengan peran punokawan, seperti Petruk, Bagong, atau Gareng. Kalaupun ada biasanya terfokus pada kajian tentang peran Semar sebagai punokawan 
yang sebenarnya ia adalah dewa (Siswanto, 2019; Habsy, 2017). Sosok Petruk sebagai punokawan cerdik layak untuk dikaji dengan berbagai kelebihan dan kekurangannya. Namun, dalam kajian ini yang menjadi objeknya bukan pada lakon wayang yang memerankan Petruk, tetapi lukisan yang menggambarkan sosok Petruk dengan sosok-sosok yang mengelilinginya.

Tujuan penelitian ini adalah untuk mengetahui dan mendeskripsikan makna lukisan Subandi Giyanto berjudul Petruk Dadi Ratu, Semare Kaling-kalingan Mega terkait dengan pendidikan karakter. Karakter merupakan perilaku manusia yang berhubungan dengan Tuhan Yang Maha Esa, diri sendiri, sesama manusia, lingkungan dan kebangsaan yang terwujud dalam pikiran, sikap, perasaan, perkataan, dan perbuatan berdasarkan normanorma agama, hukum, tata krama, budaya, dan adat istiadat (Kementerian Pendidikan Nasional, 2010: 12-13). Pendidikan karakter yang baik harus melibatkan pengetahuan yang baik (moral knowing), perasaan yang baik atau loving good (moral feeling) dan perilaku yang baik (moral action) sehingga terbentuk perwujudan kesatuan perilaku dan sikap hidup peserta didik (Komara, 2018; Lickona, 1991: 51). Nilai pendidikan yang terdapat dalam lukisan dikaitkan dengan nilai pendidikan budaya dan karakter bangsa yang bersumber dari pandangan hidup atau ideologi bangsa Indonesia (Pancasila), agama, budaya, dan tujuan pendidikan nasional. Terdapat lima nilai-nilai utama pendidikan karakter yang disesuaikan dengan Gerakan Nasional Revolusi Mental (GNRM), kearifan lokal, dan kreativitas nasional yaitu religius, nasionalis, mandiri, gotong royong, dan integritas (Budhiman, 2017: 10). Nilai-nilai pendidikan karakter tersebut yang nantinya ditemukan pada lukisan Subandi Giyanto berjudul Petruk Dadi Ratu, Semare Kaling-Kalingan Mega berdasarkan makna yang terkandung di dalamnya.

\section{METODE}

Penelitian ini menggunakan metode kualitatif dengan jenis penelitian berupa studi naratif. Pada studi naratif, penelitian dimulai dari pengalaman yang diekspresikan dalam cerita yang disampaikan oleh individu dan penulis mencari cara untuk menganalisis dan memahami cerita tersebut (Creswell, 2015: 96). Cerita pada penelitian ini diungkapkan dalam bentuk lukian berjudul Petruk Dadi Ratu, Semare Kaling-Kalingan Mega. Cara yang digunakan untuk menganalisis dan memahami makna lukisan menggunakan metode semiotika Pierce. Menurut Pierce (Budiman, 2017: 17), sebuah tanda (representamen) merupakan sesuatu yang bagi seseorang mewakili sesuatu yang lain dalam beberapa hal atau kapasitas. Dengan metode ini tanda-tanda yang terpresentasi dikategorikan menjadi icon, indeks, dan simbol. Tanda-tanda yang telah dianalisis kemudian diinterpretasi sehingga terungkap makna lukisan. Makna lukisan kemudian dianalisis kembali untuk menemukan nilai pendidikan karakter.

Objek material penelitian berupa lukisan Petruk Dadi Ratu, 
Semare Kaling-Kalingan Mega. Objek formalnya yaitu makna simbolik dan pendidikan karakter. Subjek penelitian adalah figur-figur wayang dalam lukisan berjudul Petruk Dadi Ratu, Semare KalingKalingan Mega. Sumber data penelitian yaitu Subandi Giyanto sebagai pelukis lukisan tersebut dan Sindhunata sebagai penulis seni rupa. Data-data penelitian diperoleh dengan cara observasi partisipatif pasif, wawancara semi terstruktur, dan dokumentasi. Wawancara dilakukan dengan Subandi Giyanto (pembuat lukisan), Sindhunata (Kurator dan penulis), dan Rommy Hendrawan (pembuat wayang). Keabsahan data dilakukan dengan keterlibatan jangka panjang, trianguasi, dan deskripsi yang kaya. Analisis data dalam penelitian menggunakan teknik interaktif model Miles dan Huberman (1994) dengan langkah-langkah meliputi pengumpulan data, reduksi data, penyajian data, dan penarikan simpulan.

\section{HASIL DAN PEMBAHASAN \\ Hasil \\ Riwayat Hidup Pelukis Subandi Giyanto}

Drs. Subandi Giyanto adalah seorang pelukis yang berkarya di Yogyakarta dan mengangkat wayang sebagai subjek lukisan. Laki-laki yang dipanggil pak Bandi ini lahir di Bantul pada tanggal 22 Juni 1958. Ia telah menempun pendidikan formal dari Sekolah Dasar (SD) pada tahun 1971, Sekolah Menengah Pertama (SMP) pada tahun 1974, Sekolah Seni Rupa Indonesia (SSRI) tahun 1979, dan Institut Keguruan dan Ilmu Pendidikan (IKIP) Negeri
Yogyakarta Jurusan Pendidikan Seni Rupa pada tahun 1986. Ia Dusun Gendeng RT 05/ RW 02 No.178, Desa Bangunjiwo, Kecamatan Kasihan, Kabupaten Bantul, Provinsi Daerah Istimewa Yogyakarta. Kegiatan berkesenian Subandi Giyanto dimulai sejak kelas satu SD, yaitu pada usia 7 tahun. Pada saat itu Subandi belajar natah dan nyungging wayang kulit dari ayahnya, Giyanto Wiguna. Kesenian Subandi mulai tersalurkan pada saat kelas 4 SD. Oleh gurunya, Pardjijo, ia diajak untuk mengikuti pameran dan lomba kerajinan Porseni SD dari tingkat IPDA sampai tingkat Provinsi di Yogyakarta dan selalu mendapat juara pertama dari tahun 1969 hingga tahun 1971. Subandi Giyanto mulai mengenal seni selain wayan kulit pada tahun 1975 saat masuk SSRI (sekarang Sekolah Menengah Seni Rupa [SMSR]). Di tahun yang sama tepatnya awal April 1975, perkenalannya dengan seni-seni yang lain ini karena guru Subandi, Supono P.R., mengajak mendatangi ulang tahun Sanggar Bambu.

Dengan bersekolah di SSRI inilah Subandi Giyanto seolah-olah menemukan dunianya. Hal ini ia buktikan melalui pameran ulang tahun SSRI di Gallery Senisono (sekarang sisi selatan Gedung Agung Yogyakarta) dan memperoleh Piagam Penghargaan Pratita Adhi Karya untuk ukir kulit (wayang).

Ide membuat lukisan wayang Subandi Giyanto bermula ketika ia sekolah di Sekolah Seni Rupa Indonesia (SSRI) yang berlokasi di Akademi Seni Rupa Indonesia (ASRI) Gampingan Yogyakarta. Saat itu Subandi sering melihat kakakkakak kelasnya di Sekolah Tinggi 
Seni Rupa Indonesia (STSRI) "ASRI" melukis di halaman kampus dengan ukuran yang besar-besar. Semua karya yang dikerjakan dengan bentuk yang ekspresif. Dari situlah Subandi berpikir seandainya ia melukis wayang mungkin akan menjadi sesuatu yang berbeda, karena waktu itu di STSRI "ASRI" tidak ada yang melukis wayang.

Ide melukis wayang semakin kuat ketika ia tahu dan sering mendengar kabar bahwa lukisanlukisan mahasiswa STSRI "ASRI", dosen STSRI "ASRI", dan guru-guru SSRI yang hanya dikerjakan selama satu atau tiga hari dapat laku dengan mahal. Terlebih setelah Subandi berkunjung di rumah pelukis Affandi. Affandi bercerita banyak tentang lukisan, karyanya dikerjakan dengan cepat, dan harga lukisannya mahal. Kondisi ini sangat berbeda dengan wayang yang sudah ia kenal. SSRI menjadi awal Subandi Giyanto mengikuti pameran bersama. Selain aktif berpameran, Subandi juga bergabung dengan komunitas Sanggar Bambu dan membuat komunitas lain untuk melakkan pameran bersama. Komunitas lain yang diikuti Subandi antara lain Kelompok 79, Kelompok 81, Kelompok Ganksal, Kelompok 11, Rumpun Muda Seni Rupa, dan Nirmana.

Lukisan wayang Subandi Giyanto mengangkat unsur-unsur tradisi dan unsur primitif yang menyatu dengan unsur modern menjadi satu kesatuan yang indah, artistik, dan bernilai estetik. Selain mengangkat wayang sebagai objek visual, hampir semua karya Subandi ada kaitannya dengan cerita wayang. Untuk isi lakon dalam wayang itu diisi dengan lakon kehidupan yang terjadi saat ini, karena pada hakikatnya kita adalah wayang juga (wawancara denan Subandi Giyanto, 3 Januari 2019). Sindhunata, seorang kurator, berpendapat bahwa karyakarya Subandi Giyanto akarnya tradisi tetapi mencoba terus mengakomodasikan dengan tuntutan seni-seni kontemporer dengan daya adaptasi yang lumayan tinggi (wawancara dengan Sindhunata, 9 Februari 2019).

Subandi Giyanto aktif berpameran sejak tahun 2004. Ia sering berpameran di Yogyakarta, Jakarta, dan Surakarta. Selain itu ia juga pernah berpameran di Bogor, Tuban, Semarang, Magelang, Ambon, California, dan Malang. Pada bulan Mei tahun 2019, Subandi melangsungkan pameran tunggal bertema Nunggak Semi di Bentara Budaya Yogyakarta. Eksistensi yang dibangun Subandi sejak tahun 2004 dengan aktif berkesenian menghasilkan tiga lukisannya dikoleksi Galeri Nasional Indonesia di Jakarta.

\section{Lukisan Petruk Dadi Ratu, Semare Kaling-Kalingan Mega}

Karya lukisan wayang dari Subandi Giyanto yang menjadi objek kajian dalam penelitian ini yaitu lukisan Petruk Dadi Ratu, Semare Kaling-Kalingan Mega. Untuk lebih jelas tentang lukisan wayang dari Subandi ini dapat dilihat gambar 1 berikut. 


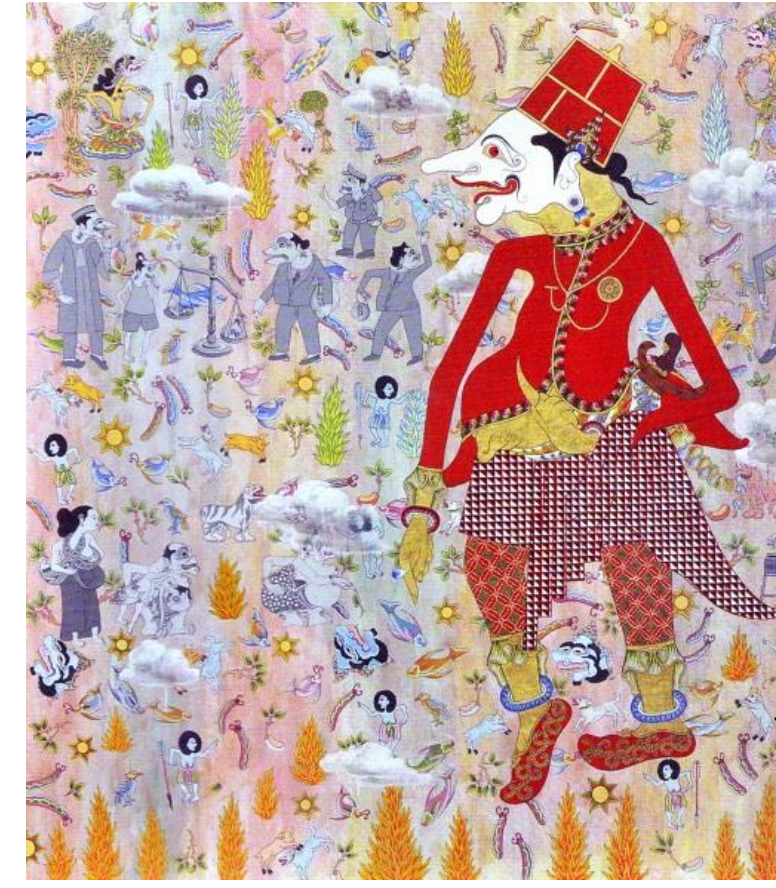

Gambar 1. Lukisan Petruk Dadi Ratu, Semare Kaling-Kalingan Mega

\section{Lukisan berjudul Petruk Dadi}

Ratu, Semare Kaling-Kalingan Mega. Terjemahan bebas dalam bahasa Indonesia judul lukisan yaitu Petruk Menjadi Raja dan Semar Terhalang Awan. Lukisan ini dikerjakan di tahun 2017. Ukuran lukisan tinggi $140 \mathrm{~cm}$ dan panjang $136 \mathrm{~cm}$. Lukisan dikerjakan dengan menggunakan bahan cat akrilik (acrylic) dan prada emas pada media canvas. Selanjutnya untuk membuat bagian detail seperti isen-isen menggunakan media tinta berwarna hitam. Lukisan ini pertama dipamerkan pada pameran kelompok Ilange Semar pada tahun 2017. Pameran bertempat di Bentara Budaya Yogyakarta (BBY). Kemudian dipamerkan kembali pada pameran tunggalnya yang bertema Nunggak Semi pada tahun 2019 di Bentara Budaya Yogyakarta.

Bentuk lukisan Subandi Giyanto yang berjudul Petruk Dadi
- Ratu, Semare Kaling-Kalingan Mega menggambarkan sebuah pertunjukan waȳang. Objek yang paling mencolok adalah figur Petruk yang memakai pakaian seorang raja berwarna merah. Ukuran Petruk yang hampir memenuhi setengah bagian karya menjadikan figur ini sebagai point of interest lukisan. Pada setiap sudut lukisan ada bagian-bagian dari cerrita mulai dari perundingan antara Petruk (berpakaian hakim), Gareng (memakai kaos tidak berlengan dan Berçelana pendek), Togog (memakai jas membawa karung bertulis “\$”), Bilung (memakai jas membawa karung bertulis “\$”), Semar berpakaian polisi, dan sebuah timbangan yang menunjukkan karung bertulis "Rp" lebih berat dari buku bertulis "KUHP" di bagian kiri atas lukisan; Petruk dan Gareng sama-sama sedang menggigit jari. Figur Petruk memakai jas berpeci yang tertawa bahagia memanggul karung bertuliskan " $\$$ " di bagian kanan atas lukisan. Kehamilan Emban Ayu dan ketiga anaknya, Bagong, Gareng, serta Semar yang tertutup awan berkepala Sengkuni di bagian kiri bawah lukisan. Figur Gareng yang menjadi pemuka agama sedang memasukkan uang (tulisan “\$”) ke dalam kotak infak di bagian kanan bawah lukisan. Semua figur berdiri pada objek-objek wuku Pahang yang tersebar di seluruh permukaan lukisan. Awan-awan berkepala Sengkuni juga tersebar di lukisan dan menutupi beberapa bagian objek pawukon. Lukisan terasa panas dengan latar belakang yang didominasi warna panas ditambah dengan objek-objek api menyala yang memenuhi bagian bawah lukisan. 
Makna Lukisan Petruk Dadi Ratu, Semare Kaling-Kalingan Mega

Secara garis besar Subandi menjelaskan bahwa ide dari lukisan Petruk Dadi Ratu, Semare KalingKalingan Mega adalah pemimpin atau presiden baru telah berganti sejak pemilu tahun 2014 namun kondisi negara tidak banyak berubah. Korupsi masih merajalela di manamana. Dari keadaan yang seperti itu mungkin pamomong negeri yang seharusnya menasihati dan memberi masukan sedang bersembunyi. Para pamomong sedang bersemedi atau memang sengaja menyembunyikan diri untuk melihat akan seperti apa nantinya. Presiden baru yang berlatar belakang orang biasa digambarkan dengan Petruk. Semar, sebagai pamomong, digambarkan sedang bersembunyi atau disembunyikan di balik awan.

Berdasarkan ide penciptaan Subandi Giyanto tersebut terdapat makna pada judul lukisan yaitu Petruk Dadi Ratu, Semare KalingKalingan Mega. Judul lukisan yaitu Petruk Dadi Ratu, Semare KalingKalingan Mega merupakan tanda berjenis simbol dalam semiotika Pierce yang merujuk pada makna lukisan. Tabel 1 berikut menjelaskan trikotomi pada judul lukisan Petruk Dadi Ratu, Semare Kaling-Kalingan Mega.

Tabel 1. Trikotomi Makna Lukisan Petruk Dadi Ratu, Semare Kaling-Kalingan Mega.

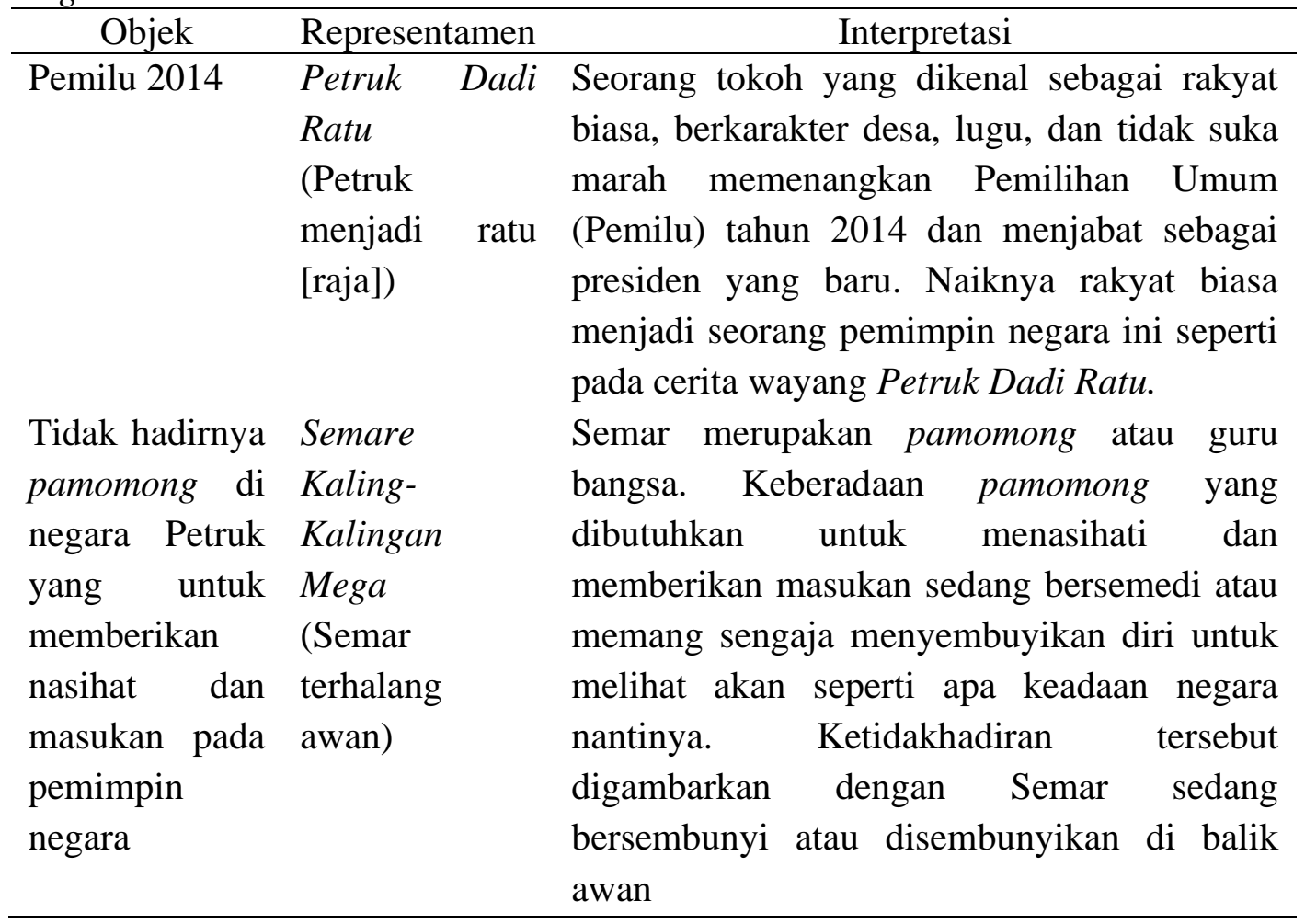

Subandi Giyanto menjelaskan bahwa hampir semua lukisannya ada kaitannya dengan cerita wayang dan terkadang cerita wayang yang 
digunakan disesuaikan dengan kondisi kehidupan saat ini (wawancara Subandi Giyanto tanggal 3 Januari 2019). Hasil interpretasi pada judul lukisan mengarahkan pada satu cerita wayang yaitu Petruk Dadi Ratu. Petruk dalam kisah Ambangan Candi Spataharga atau Saptaraga, Dewi Mustakaweni puteri dari negara Imantaka, diceritakan berhasil mencuri Jamus Kalimasada dengan cara menyamar sebagai kerabat Gatotkaca (Endraswara, 2014: 21). Dikisahkan bahwa Kalimasada menjadi rebutan antara Bambang Priyambada dan Dewi Mustakaweni. Di dalam kekacauan dan kekeruhan tersebut Petruk mengambil kesempatan untuk menyembunyikan Kalimasada. Karena kekuatan dan pengaruh Kalimasada yang ampuh kemudian Petruk dapat menjadi raja dengan menduduki singgasana di kerajaan Lojitengara dengan nama Prabu Welgeduwelbeh.

kesaktiannya Petruk mampu membuka rahasia Prabu Pandupragola, raja negara Tracanggribig, yaitu kakaknya sendiri Nala Gareng. Namun sebaliknya, Bagong kemudian berhasil menurunkan Prabu Welgeduwelbeh dari tahtanya dengan membongkar rahasianya menjadi Petruk kembali. Kalimasada kemudian dikembalikan pada Puntadewa. Lakon tersebut berjudul Petruk Dadi Ratu.

Apa yang tersirat dalam lukisan Subandi Giyanto berjudul Petruk Dadi Ratu, Semare KalingKalingan Mega merupakan representasi pelukis untuk menggambarkan kondisi negara yang sedang dipimpin oleh Petruk. Negara yang dimaksud adalah negara ketika Petruk menjadi ratu. Ketika itu seorang rakyat biasa terpilih menjadi seorang presiden atau pemimpin negara. Pada saat itu terjadi kondisi sosial sedang memanas, negara sedang kacau. Ketidakadilan, suapmenyuap, korupsi, kemiskinan, dan pencitraan menjadi makanan seharihari di negara Petruk. Sementara itu sang Petruk yang rakyat biasa harus berdiri sendiri sebagai pemimpin untuk menanggung segala permasalahan yang terjadi di negaranya.

Sedangkan Semar; sang tetua, sang guru bangsa, atau sang pamomong; yang harusnya ngemong, mengasuh, memberikan petuah dan nasihatnya malah memilih diam. Diam ini karena bersembunyi, disembunyikan, hilang, atau justru karena dilupakan. Sang pamomong dilupakan karena di negara itu banyak Petruk-Petruk (rakyat biasa) lain yang ingin menjadi Ratu tanpa peduli dengan sang pamomong. Ada satu hal yang bisa menjadi indikasi penyebab terjadinya kondisi sosial tersebut yaitu adanya tokoh-tokoh yang tidak rela ketika Petruk menjadi pemimpin. Mereka adalah tokohtokoh antagonis yang memiliki sifat seperti Sengkuni.

Para Sengkuni menyamar dalam bentuk awan dan menghalanghalangi, menutupi, serta menaungi semua kejadian yang terjadi. Awanawan membuat semua kejadian menjadi abu-abu, blur antara baik dan buruk, baik buruk adalah hal biasa dan baik-baik saja. Itulah potret negara yang sedang memanas, negara yang hidup dalam wuku Panggah yang menggambarkan pulo katon saka ing kadohan (pulau 
tampak dari kejauhan) yaitu negara yang terlihat baik namun sebenarnya sedang terjadi keprihatinan atau kesedihan di dalamnya.

Sindhunata berpendapat bahwa sini ilang-nya Semar itu fatal. Hilang seperti hilangnya kebudayaan. Konteks Petruk Dadi Ratu dalam lukisan Subandi Giyanto mungkin mengkritik keadaan sekarang yang banyak orang mau menjadi Ratu tetapi lupa bahwa sebenarnya mereka harus menghormati Semar. Itulah yang mengakibatkan Semar KalingKalingan Mega (wawancara Sindhunata tanggal 9 Februari 2019).
Metode yang digunakan untuk memaknai lukisan berjudul Petruk Dadi Ratu, Semare KalingKalingan Mega adalah semiotika Pierce. Semiotika berfungsi untuk menafsirkan atau menterjemahkan makna dari simbol-simbol yang dipakai Subandi Giyanto dalam karyanya. Tabel 2 berikut memaparkan analisis tanda yang dikategorikan dalam jenis tanda sesuai turunan trikotomi tingkat secondnes.

Tabel 2. Jenis Tanda dalam Lukisan Petruk Dadi Ratu, Semare KalingKalingan Mega

\begin{tabular}{lll}
\hline \multicolumn{1}{c}{ ICON } & \multicolumn{1}{c}{ INDEX } & \multicolumn{1}{c}{ SYMBOL } \\
\hline 1. Petruk Ratu & 1. Timbangan & 1. Karung bertuliskan \\
2. Petruk hakim & 2. Awan & \$ dan Rp \\
3. Gareng & 3. Objek pawukon & 2. Warna grayscale \\
4. Semar polisi & (Raden Pahang, & 3. Emban Ayu dan \\
5. Buku "KUHP" & Batara Tantra, Batara & Bagong \\
6. Semar & Kala, pohon, & menggendong \\
7. Sengkuni & paringkelan, kayu & Gareng \\
8. Petruk berjas & kendayakan, ulat, & 4. Latar belakang \\
9. Togog berjas & bintang, singa, & warna panas \\
10. Bilung berjas & banteng, anjing, ikan, & \\
11. Gareng kiai dan & dan burung cucak) & \\
Kotak infaq & 4. Objek pawukon api & \\
\hline
\end{tabular}

Dalam lukisan Subandi Giyanto, tokoh Petruk dalam Petruk Dadi Ratu dapat mempunyai dua makna. Pertama Petruk sebagai representasi tokoh Petruk dalam cerita Petruk Dadi Ratu atau Prabu Welgeduwelbeh yaitu seorang rakyat biasa yang menjadi pemimpin atau naik tahta menjadi raja. Kedua, figur Petruk dapat diartikan secara luas yang menunjukkan masa ketika Petruk menjadi seorang ratu.
Selain Petruk, terdapat figurfigur lain di sekitar Petruk. Figurfigur tersebut memenuhi seluruh bagian lukisan. Semua figur dapat dimaknai sebagai lingkungan Petruk. Lingkungan yang menunjukkan ketika Petruk tersebut menjabat sebagai Ratu. Figur-figur tersebut berupa Petruk, Gareng, Semar, Togog, Bilung, Emban Ayu, Bagong, Awan, dan objek-objek pawukon yaitu Raden Pahang, Batara Tantra, 
Batara Kala, api, pohon, paringkelan, kayu kendayakan, ulat, bintang, singa, banteng, anjing, ikan, dan burung cucak. Menurut Subandi figur-figur tersebut yang terdiri dari binatang, tumbuhan, dan unsur alam menggambarkan tentang alam lingkungan. Alam merupakan bagian dari kehidupan khusunya manusia. Kehidupan tidak dapat terlepas dan selalu berkaitan dengan lingkungan sekitar (wawancara Subandi Giyanto tanggal 3 Januari 2019).

Apa yang terjadi ketika Petruk menjadi Ratu dapat dilihat dari dua sisi yaitu kondisi sosial dan kondisi alam. Kondisi sosial digambarkan dengan figur-figur Petruk, Gareng, Togog, Semar, Bilung, Emban Ayu, dan Bagong. Sedangkan kondisi alam digambarkan dengan objek-objek pawukon yaitu Raden Pahang, Batara Tantra, Batara Kala, api, pohon, paringkelan, kayu kendayakan, ulat, bintang, singa, banteng, anjing, ikan, dan burung cucak.

Kondisi sosial digambarkan Subandi Giyanto ke dalam empat bagian yang semuanya digambarkan dengan figur-figur berwarna grayscale. Bagian-bagian tersebut terletak pada bagian kiri atas lukisan, kanan atas lukisan, kiri bawah lukisan, dan kanan bawah lukisan. Pertama, bagian kiri atas lukisan terdapat seperti sebuah adegan di mana Gareng (memakai kaos tidak berlengan dan celana pendek) dan Petruk (memakai baju hakim) keduanya saling menggigit jari. Di sampingnya Togog dan Bilung yang sama-sama memakai baju jas seperti seorang pejabat membawa uang dalam karung bertulis \$ (Dollar). Di antara Gareng dan Togog terdapat neraca (timbangan) yang menunjukkan karung uang (karung bertulis Rp [Rupiah]) lebih berat dari pada buku bertulis KUHP (Kitab Undang-Undang Hukum Pidana). Sedangkan Semar yang memakai pakaian polisi hanya dapat mengacungkan jempolnya.

Pada bagian pertama tersebut menggambarkan bagaimana kondisi sosial yang tidak adil yaitu jual-beli hukum. Di negara Petruk hukum dapat dibeli dengan uang. Hal tersebut ditunjukkan dengan timbangan yang berat sebelah. Uang (karung bertulis Rp) lebih berat dari pada hukum (buku KUHP). Pejabat dapat menyuap dan disuap yang digambarkan dengan Togog dan Bilung membawa karung bertulis \$. Hakim yang jujur (Petruk Hakim) dan rakyat (Gareng) hanya bisa menonton sambil menggigit jari karena tidak bisa berbuat apa-apa. Bahkan polisi sebagai pihak penegak hukum tidak dapat berbuat banyak, polisi hanya bisa mengacungkan jempol seperti menunjukkan bahwa kondisi seperti itu adalah hal yang baik atau mengatakan bahwa apa yang terjadi sudah aman tanpa diketahui oleh rakyat yang digambarkan dengan Semar berpakaian polisi mengacungkan jempolnya.

Kondisi sosial pada bagian kedua yaitu terletak pada kanan atas lukisan terdapat adegan Petruk yang memakai setelan jas, sedang tertawa, dan memanggul satu karung yang bertuliskan \$ (Dolar). Pada bagian kedua menggambarkan seorang pejabat negara yaitu Petruk berjas adalah pejabat yang suka korupsi. Petruk menggambarkan seorang pejabat yang bekerja untuk 
memperkaya dirinya sendiri yang bangga (tertawa) dengan uang yang dimilikinya dari hasil korupsi (karung bertulis \$).

Bagian ketiga yaitu adegan yang terdapat pada bagian kiri bawah lukisan. Pada bagian ini Subandi menggambarkan Emban Ayu yang sedang hamil menggendong tiga anak. Menurut pendapat Rommy Hendrawan (wawancara, 20 Maret 2019), Emban Ayu sebenarnya adalah figur mbok Brayut. Mbok Brayut adalah seorang perempuan dengan banyak anak. Mbok Brayut merupakan lambang kesuburan. Di sebelah Emban Ayu terdapat Bagong yang sedang membopong Gareng yang terlihat sangat kurus dan lemah. Ketiga figur ini menggambarkan tentang kondisi bumi atau negara yang subur namun rakyatnya miskin dan kelaparan.

Pada bagian ketiga ini juga terdapat figur Semar yang kepalanya tertutup oleh awan. Pada awan tersebut terdapat kepala Sengkuni. Semar terlihat seperti tersembunyi atau bersembunyi di balik awan. Hal ini seperti pada bagian judul lukisan yaitu Semare Kaling-Kalingan Mega. Sebagai abdi, Semar juga bertugas untuk ngemong, mengasuh, memberikan nasihat pada para Pandawa. Semar adalah pamomong, yang ngemong, mengasuh, dan memelihara kehidupan di tanah Jawa (Sindhunata, 2017: 13). Namun, yang terjadi Semar tertutup oleh awan. Semar sedang bersembunyi, disembunyikan, atau dilupakan sehingga ia bersembunyi di balik awan. Menurut Subandi, kemungkinan "Pamomong di Jawa ini” mungkin baru ngumpet, bersembunyi atau mungkin sedang bersemedi di tempat lain atau dia sengaja melihat biar situasinya sampai puncak itu sepeti apa, sehingga dia tidak muncul di situ (wawancara dengan Subandi Giyanto, 3 Januari 2019). Awan yang digunakan oleh Semar bersembunyi terdapat tokoh Sengkuni. Tokoh Sengkuni merupakan tokoh antagonis dengan sifat jahat seperti penghasut, licik, suka mengadu domba, pemfitnah, sombong, congkak, tinggi hati, suka merendahkan orang lain, mengambil hak orang lain, mementingkan urusan pribadi dan melupakan kepentingan orang banyak, iri hati, serta suka mencelakakan orang lain (Hariwidjoyo, 2011: 170). Sedangkan menurut Subandi, pamomong ialah guru bangsa. Guru bangsa adalah siapa saja seperti mantan pemimpin, mantan tokoh, mantan kiai, atau yang selalu bisa memberi petunjuk baik dan mencerahkan. Guru bangsa merupakan orang yang mau melindungi dan menerima siapa saja baik itu mayoritas maupun minoritas tanpa kecuali. Guru bangsa merupakan orang yang netral dan tidak memiliki kepentingan apapun (wawancara dengan Subandi Giyanto, 3 Januari 2019). Dengan demikian, figur Semar yang tertutup oleh awan berwajah Sengkuni dapat berarti bahwa dalam kondisi sosial yang terjadi sosok pamomong atau guru bangsa yang harusnya mampu menasihati dan diperlukan nasihat atau petuahnya justru malah diam atau menghilang (bersembunyi). Hilangnya sosok pamomong tersebut karena ia disembunyikan oleh tokohtokoh antagonis bersifat Sengkuni yang tidak rela ketika rakyat biasa 
menjadi pemimpin (dipimpin oleh rakyat biasa) atau justru sang Petruk (pemimpin) merasa mampu mengelola negara sehingga sudah tidak membutuhkan figur pamomong lagi.

Pada bagian keempat Subandi menggambarkan tokoh Gareng yang berpenampilan seperti seorang ustaz atau kiai (memakai peci, baju koko, dan sarung serta memiliki jenggot) sedang memasukkan uang ke dalam kotak infak. Berdasarkan ketiga bagian adegan yang digambarkan oleh Subandi Giyanto bagian keempat inilah satu-satunya adegan yang memperlihatkan tindakan baik atau positif yaitu menyumbangkan sebagian harta yang dimiliki untuk orang lain. Jika dikaitkan dengan konteks kondisi sosial yang kurang baik seperti pada ketiga bagian yang lain, apa yang dilakukan Gareng menjadi tidak baik pula. Yang menjadi pertanyaan adalah mengapa Subandi Giyanto memunculkan Gareng yang sedang bersedekah? Mungkinkah sedekah yang sejatinya adalah perbuatan baik lantas dalam lingkungan sosial dalam lukisan menjadi buruk? Bukankah perbuatan baik seharusnya tidak ditunjukkan? Jawaban yang mungkin adalah pada konteks negara yang sedang kacau perbuatan baik (bersedekah) akan menjadi hal buruk jika ditunjuktunjukkan, diperlihatkan, atau disombongkan. Perbuatan baik itu akan semakin buruk jika tujuannya hanya untuk pencitraan semata, supaya orang lain menilai bahwa tokoh itu orang yang baik padahal ada tujuan lain di baliknya.

\section{Pembahasan}

\section{Memaknai lukisan Petruk Dadi Ratu, Semare Kaling-Kalingan Mega}

Berdasarkan keempat bagian adegan figur-figur dalam lukisan Petruk Dadi Ratu, Semare KalingKalingan Mega tersebut jelaslah bagaimana kondisi sosial yang sedang terjadi. Subandi melihat negara Petruk dalam keadaan yang kacau dengan berbagai permasalahannya. Kemudian yang terjadi adalah keempat bagian adegan semua figur digambarkan dengan warna grayscale yaitu bernuansa monokrom yang mempunyai rentang dari hitam menuju putih dan berskala abu-abu. Selain itu pada bagian atas figur-figur berwarna grayscale ada objek awan berkepala Sengkuni. Dengan tertutupnya awan, apa yang dilakukan figur di bawahnya menjadi bersifat buruk atau negatif. Hal ini sesuai dengan keempat bagian adegan yang digambarkan dan tertutup atau terhalangi oleh awan. Objek awan dikerjakan dalam bentuk realistik atau nyata yang dapat menegaskan bahwa semua yang sedang terjadi memang nyata adanya. Figur-figur yang berwarna abu-abu (grayscale) menunjukkan bahwa apa saja yang dilakukan terlihat memiliki sifat abu-abu. Perbuatan yang sudah bercampur antara hitam (buruk) dan putih (baik). Perbuatan buruk dianggap baik dan perbuatan baik digunakan dengan buruk sehingga semua terlihat samar-samar antara baik dan buruk. Semua perbuatan yang terjadi dianggap lumrah dan baik-baik saja.

Kondisi alam yang terjadi, digambarkan Subandi Giyanto dengan menggunakan objek-objek pada pawukon. Pawukon yang dipilih 
adalah wuku Pahang. Wuku Pahang memiliki objek berupa Raden Pahang, Batara Tantra, Batara Kala, api, pohon, paringkelan, kayu kendayakan, ulat, bintang, singa, banteng, anjing, ikan, dan burung cucak. Agar lebih jelas tentang wuku pahang ini silakan dicermati gambar 2 di bawah ini.

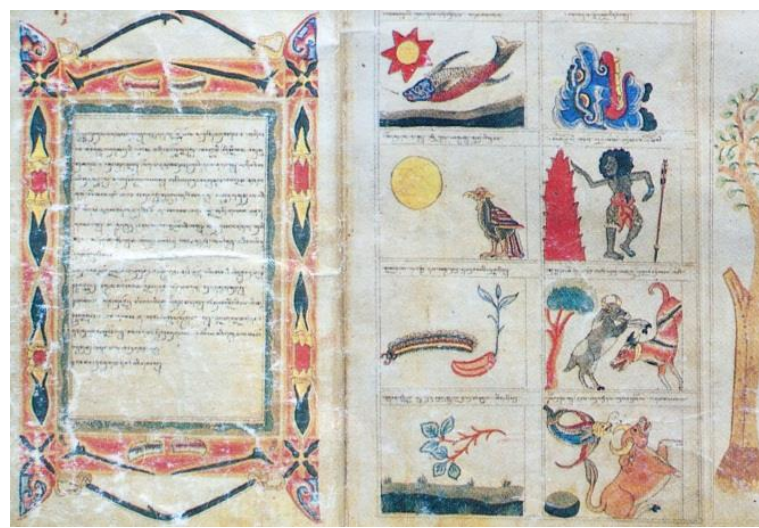

Gambar 2. Wuku Pahang (Sumber: Mulyono, 1993: 122)

Meskipun Subandi Giyanto menggunakan objek-objek pawukon untuk menunjukkan lingkungan alam namun pawukon sendiri juga menandakan waktu. Menurut Hermanu (2013: 35) pawukon merupakan ilmu yang mempelajari tentang waktu dan hari lahir serta sifat-sifat bawaan seseorang. Wuku yang terjadi saat Petruk menjadi ratu adalah wuku Pahang. Candra atau gambaran wuku Pahang adalah pulo katon saka ing kadohan (pulau tampak dari kejauhan) (Mulyono, 1993: 122). Candra tersebut berarti berwatak termasyur dalam segala hal dan suci atau baik ketika dilihat dari luar, tetapi sebenarnya di dalam batin selalu prihatin, masygul atau sedih (Djanudji \& Doyodipuro, 1999: 138139). Dengan wuku yang seperti itu dapat menjelaskan bahwa apa yang sebenarnya terjadi pada negara
Petruk tidak sesuai dengan apa yang terlihat. Negara yang besar, gagah, adil, dan makmur namun terjadi keprihatinan dan kesedihan di dalamnya. Keprihatinan tersebut diakibatkan karena kondisi sosial yang sedang terjadi yang membuat negara begitu kacau.

Di dalam wuku Pahang ini, terdapat objek yang sangat ditonjolkan oleh Subandi yaitu objek api. Api yang berkobar dengan warna kombinasi warna merah dan oranye memenuthe bagian bawäh Tukisan. Api yang besar ditambah dengan penggunaan latar belakang (baekground) yang didominasi warna merah y menggambarkan suasana lukisanyang panas. Haltersebut jugá berdampak pada makna bahwwa negara sang Petruk sedang panas. Panasnya kondisi sosial yang terjadi seolah-olah seperti api yang menyala sangat besar sehingga membuat hawa disekitarnya ikut memanas.

\section{Nilai-nilai Karakter pada Makna Lukisan Petruk Dadi Ratu, Semare Kaling-Kalingan Mega}

Nilai-nilai karakter dari lukisan Petruk Dadi Ratu, Semare Kaling-Kalingan Mega diperoleh dari citraan lukisan yaitu bentuk dan warna serta makna yang terkandung di dalamnya. Sesuai dengan nilainilai pendidikan karakter yang dicanangkan oleh Kementerian Pendidikan dan Kebudayaan Republik Indonesia terdapat tiga nilai pokok yang ada pada makna lukisan tersebut, yaitu integritas, nasionalis, dan mandiri.

a. Integritas

Karakter integritas ditunjukkan dengan sikap jujur dan tanggung jawab. Perilaku jujur 
adalah perilaku yang menjadikan dirinya sebagai orang yang selalu dapat dipercaya dalam perkataan, tindakan, dan pekerjaan. Karakter jujur merupakan salah satu karakter pokok yang ditargetkan sejak awal dicanangkannya pendidikan karakter bangsa di Indonesia di samping karakter cerdas, tangguh, dan peduli (Marzuki, 2012). Pada lukisan Petruk Dadi Ratu, Semare Kaling-Kalingan Mega memang tidak menunjukkan secara langsung perilaku jujur. Namun, perilaku jujur ini sangat diperlukan pada kondisi sosial seperti pada negara Petruk. Perilaku yang ditunjukkan seperi hakim yang disuap, peradilan yang berat sebelah, pejabat yang saling sogokmenyogok, pejabat yang korupsi, dan pencitraan dapat dilawan dengan sikap jujur. Seorang pejabat atau wakil rakyat harus memiliki sifat jujur. Sifat jujur inilah yang akan menjadi modal kepercayaan bagi rakyatnya.

Tanggung jawab merupakan sikap dan perilaku seseorang untuk melaksanakan tugas dan kewajiban, yang seharusnya dilakukan terhadap diri sendiri, masyarakat, lingkungan (alam, sosial dan budaya), negara dan Tuhan Yang Maha Esa. Begitu pentingnya karakter tanggung jawab ini sampai-sampai Lickona menjadikannya satu dari dua karakter pokok yang harus diajarkan kepada peserta didik (Lickona, 1991). Penanaman karakter tanggung jawab tidak hanya melalui pembelajaran ilmu-ilmu sosial, tetapi juga melalui pembelajaran ilmu-ilmu eksak seperti matematika (Sukmawati \& Nesvihani, 2018). Warga negara memiliki tanggung jawab pada setiap pekerjaannya. Jika seseorang memilih bekerja sebagai pemimpin atau wakil rakyat berarti ia memiliki tanggung jawab atas kebaikan dan kesejahteraan rakyatnya. Seorang pemimpin tidak boleh mementingkan dirinya sendiri. Pada lukisan Petruk Dadi Ratu, Semare Kaling-Kalingan Mega melukiskan kondisi negara yang para pemimpinnya mementingkan dirinya sendiri sehingga mengakibatkan negara menjadi kacau dan akhirnya rakyatnyalah yang menjadi korban (kemiskinan dan kelaparan). Kekacauan pada negara Petruk seperti lupanya para pemimpin pada pamomong, pamomong yang terlihat tidak mau tahu pada kondisi negara, ketidakadilan, hakim yang disuap, korupsi, dan pencitraan. Apa yang terjadi pada negara Petruk tersebut diakibatkan karena tidak adanya sikap bertanggung jawab pada pekerjaan dan jabatan yang disandangnya. Untuk itulah perlunya nilai pendidikan karakter tangung jawab ditanamkan pada seorang pemimpin. Tidak hanya pemimpin saja yang harus memiliki sikap tanggung jawab namun juga semua warga negara. Semua warga negara memiliki tanggung jawab pada kebaikan negaranya.

\section{b. Nasionalis}

Karakter nasionalis ditunjukkan dengan sikap semangat kebangsaan. Karakter semangat kebangsaan yaitu cara berpikir, bertindak, dan berwawasan yang menempatkan kepentingan bangsa dan negara di atas kepentingan diri dan kelompoknya (Marzuki \& Haq, 2018). Karakter nasionalis harus ditanamkan kepada setiap warga negara agar ia memiliki kecintaan 
terhadap negaranya dan mau berkorban untuk negara dan bangsanya (Keraf \& Komalasari, 2019). Di negara Petruk, banyak rakyat bisa yang ingin menjadi Ratu tetapi mereka lupa dengan pamomong. Di satu sisi, terdapat tokoh yang tidak rela ketika sang Petruk menjadi Ratu sehingga ia menyembunyikan pamomong (Semar) yang mengakibatkan diamnya pamomong. Berdasarkan makna lukisan tersebut dapat diinterpretasi bahwa memajukan negara adalah hak semua warga negara untuk itulah diperlukan gotong royong semangat membangun bangsa. Jabatan bukanlah segalanya karena sesungguhnya jabatan atau menjadi wakil rakyat adalah sebuah amanah dari rakyat itu sendiri. Siapa saja yang menjadi pemimpin harusnya diberikan dukungan karena dari sanalah muncul ide-ide atau gagasangagasan baru untuk merubah negara ke arah yang lebih baik. Baik itu pemimpin, pamomong, pejabat negara, dan seluruh warga negara harus saling bahu-membahu memajukan bangsa bukan saling berebut kekuasaan. Siapa pun yang menjadi pemimpin juga harus berpikir, bertindak, dan berwawasan untuk kepentingan bangsa dan negara di atas kepentingan pribadi atau kelompoknya, apalagi sampai memperkaya diri sendiri dengan cara melakukan korupsi.

\section{c. Mandiri}

Karakter mandiri adalah karakter yang sangat penting yang harus ditanamkan pada setiap diri seseorang. Orang yang mandiri akan selalu berusaha untuk melakukan pekerjaan secara benar dan penuh tanggung jawab. Ia tidak menggantungkan pekerjaannya pada orang lain. Dan jika pekerjaannya tidak berhasil, ia akan menyadari bahwa hal itu karena ulahnya sendiri, dan ia tidak berusaha mencari-cari kesalahan orang lain. Karakter mandiri harus ditanamkan dengan berbagai cara, mengingat begitu sulitnya karakter mandiri ini dimiliki seseorang (Budiyanto \& Machali, 2014).

Pada lukisan Petruk Dadi Ratu, Semare Kaling-Kalingan Mega nilai mandiri tidak akan diperoleh ketika manusia masih mempunyai sifat Sengkuni yang menjelma menjadi awan. Keberhasilan seseorang harusnya tidak ditanggapi dengan sikap iri hati. Bagi pihak yang belum bisa menjadi pemimpin harusnya bersikap rela dan ikhlas menerima kekalahan. Sikap tersebut merupakan sikap profesional. Setiap warga negara berkewajiban mendukung siapa saja yang menjadi pemimpinnya, memberikan kritikan jika ada kesalahan, dan memberikan masukan untuk memperbaikinya.

\section{PENUTUP}

Sebuah karya seni tidak hanya tersimpan nilai estetis atau keindahannya saja yang terdapat pada citraan visualnya. Terdapat nilai-nilai lain yang terkandung salah satunya adalah nilai pendidikan karakter. Pendidikan karakter bukan hanya sekedar mengajarkan mana yang benar dan mana yang salah. Hal ini terdapat dalam lukisan Subandi Giyanto berjudul Petruk Dadi Ratu, Semare Kaling-Kalingan Mega. Lukisan ini menggambarkan negara Petruk yang sedang kacau. 
Kekacauan itu seperti ketidakadilan, suap, korupsi, kelaparan, dan pencitraan. Di negara tersebut guru bangsa (Semar) disembunyikan oleh oknum-oknum antagonis yang tidak rela kalau Petruk menjadi ratu. Di sisi lain, banyak warga negaranya yang ingin menjadi ratu namun melupakan guru bangsanya. Nilai pendidikan karakter yang terkandung dalam bentuk dan makna lukisan dan sesuai dengan nilai pendidikan budaya dan karakter bangsa Kementerian Pendidikan dan Kebudayaan Republik Indonesia, yakni karakter integritas, nasionalis, dan mandiri.

\section{UCAPAN TERIMA KASIH}

Penulis mengucapkan terima kasih yang sebesar-sebesarnya kepada Bapak Subandi Giyanto yang telah berkenan lukisannya diteliti dan membagikan segala informasi untuk penelitian ini. Terima kasih juga penulis ucapkan kepada Sindhunata dan Rommy Hendrawan yang telah memberikan informasi untuk mendukung penelitian. Terima kasih juga penulis ucapkan pada semua pihak yang telah membantu dan mendukung terselesaikannya penelitian hingga ditulisnya artikel ini.

\section{DAFTAR PUSTAKA}

Arisyanto, P., Cahyono, A., \& Hartono, H. (2017). Wayang kulit wong lakon menjunjung langit mencium bumi: Kajian teks

pertunjukan. Catharsis, 6(1), 74-81.

DOI 10.15294/CATHARSIS. V6I1.17034.
Budiman, K. (2017). Semiotika Visual: Kosep, Isu, dan Problem Ikonisitas. Yogyakarta: Jalasutra

Creswell, J.W. (2015). Penelitian kualitatif \& Desain Riset: Memilih di Antara Lima Pendekatan (Edisi ke-3). (Terjemahan Ahmad Lintang Lazuardi). Yogyakarta: Pustaka Pelajar (Edisi asli diterbitkan tahun 2013 oleh SAGE)

Budhiman, A. (2017). Gerakan Penguatan Pendidikan

Karakter. Kementerian

Pendidikan dan Kebudayaan Republik Indonesia.

Budiyanto, M. \& Machali, I. (2014). Pembentukan karakter mandiri melalui pendidikan agriculture di Pondok Pesantren Islamic Studies Center Aswaja Lintang Songo Piyungan Bantul Yogyakarta. Jurnal Pendidikan Karakter, 4(2), 108-122. DOI: DOI: https://doi.org/10.21831 /jpk.v0i2.2784.

Dewantara, K. H. (2011). Bagian Pertama: Pendidikan. Yogyakarta: Majelis Luhur Persatuan Tamansiswa.

Djanudji \& Doyodipuro, K.H. (1999). Pawukon Jangkep, Nyakup ing Babagan Horoskop Jawa. Semarang: Dahara Prize

Endraswara, S. (2014). Petruk Dadi Ratu, Polah Tingkah Penguasa yang Tidak Maтpu. Yogyakarta: Narasi.

Habsy, B. A. (2017). Semar puppet counseling model. COUNSEDU: The International Journal of Counseling and 
Education, 2(1), 19-24.

DOI: https://doi.org/10.23916 /002017024410.

Hariwidjoyo, A. (2011). Wayang dan Karakter Manusia dalam Kehidupan Sehari-Hari. Yogyakarta: Absolut.

Hermanu (Ed). (2013). Pawukon 3000th. Yogyakarta: Bentara Budaya Yogyakarta

Irmayani, N. R. (2018). Fenomena kriminalitas remaja pada aktivitas geng motor. Sosio Informa, 4(2), 401-417. DOI: https://doi.org/10.33007 /inf.v4i2.1220.

Juditha, C. (2018). Hoax communication interactivity in social media and anticipation (interaksi komunikasi hoax di media sosial serta antisipasinya). Pekommas, 3 ( 1), 31-33. Retrieved from https://media.neliti.com/medi a/publications/261723-hoaxcommunication-interactivityin-soci-

2ad5c1d9.pdf?fbclid=IwAR0 oYb_NYtm7KEg4bJkX4AVrK0cBalsFKPM7W3q v051Mk1abM5iK6P_5FI.

Kementerian Pendidikan Nasional. (2011). Panduan Pelaksanaan Pendidikan Karakter. Jakarta: Badan Penelitian dan Pengembangan Pusat Kurikulum dan Perbukuan

Keraf, F. M. P. dan Komalasari, K. (2019). Habituasi untuk menguatkan karakter nasionalisme peserta didik wilayah perbatasan pada abad 21. Jurnal Pendidikan Karakter, 9(2), 216-230. DOI: https://doi.org/10.21831 /jpk.v9i2.25627.

Komara, E. (2018). Penguatan pendidikan karakter dan pembelajaran abad 21. Sipatahoenan, 4(1), 17-26 DOI: https://doi.org/10.2121/ sip.v4i1.991.

Lickona, T. (1991). Educating for character: How our schools can teach respect and responsibility. New York: Bantam Books.

Marzuki. (2012). Pengintegrasian pendidikan karakter dalam pembelajaran di sekolah. Jurnal Pendidikan Karakter, 2(1), 33-44. DOI: https://doi.org/10.21831/jpk.v $0 \mathrm{i} 1.1450$.

Marzuki \& Haq, P. I. (2018). Penanaman nilai-nilai karakter religius dan karakter kebangsaan di Madrasah Tsanawiyah Al Falah Jatinangor Sumedang. Jurnal Pendidikan Karakter, 8(1), 84-94.

DOI: https://doi.org/10.21831 /jpk.v8i1.21677.

Miles, M. B., \& Huberman, M. A. (1994). Qualitative data analysis: An expanded sourcebook (2rd ed). London: Sage Publication.

Mulyono, D. (1993). Kalender Pawukon 200 Tahun, 19002100. Surakarta: Studio Delapanpuluh Enterprise.

Octavia, E. R., \& Ismail, A. I. (2018). Penguatan branding 
desa kepuhsari Manyaran Wonogiri sebagai destinasi wisata kampung Wayang Tatah Sungging. Jurnal Industri Kreatif dan Kewirausahaan, 1(1), 32-50. DOI: http://dx.doi.org/10.364 41/kewirausahaan.v1i1.61.

Qolbiyyah, S. (2017). Kenakalan remaja (Analisis tentang faktor penyebab dan solusinya dalam perspektif pendidikan agama Islam). Sumbula: Jurnal Studi Keagamaan, Sosial dan Budaya, 2(1), 493-512. Retrieved from file://C:/Users/UNY/Downlo ads/2984-Article\%20Text7892-1-1020170710\%20(1).pdf.

Rahadi, D. R. (2017). Perilaku pengguna dan informasi hoax di media sosial. Jurnal Manajemen dan Kewirausahaan, 5(1), 58-70. DOI: https://doi.org/10.26905/jmdk .v5i1.1342.

Rofiqah, T., \& Sitepu, H. (2019). Bentuk kenakalan remaja sebagai akibat broken home dan implikasinya dalam pelayanan bimbingan konseling. KOPASTA: Jurnal Program Studi Bimbingan Konseling, 6(2), 99-107. DOI: http://dx.doi.org/10.333 73/kop.v6i2.2136.

Setiyawan, A. (2017). Tinjauan kriminologi terhadap tindak pidana penganiayaan yang dilakukan oleh geng motor di wilayah Kota Cirebon (Studi kasus Polres Kota Cirebon). Doctoral
Dissertation. $\quad$ Semarang: Fakultas Hukum UNISSULA. Retrieved from http://repository.unissula.ac.i $\mathrm{d} / \mathrm{id} /$ eprint/7346.

Setyawan, B. W. (2020). Environment preserving character on wayang story dewa ruci: an ecological literature study. Jurnal Kata: Penelitian tentang Ilmu Bahasa dan Sastra, 4(1), 122132. DOI: http://doi.org/10.22216/kata.v $4 \mathrm{i} 1.5185$.

Sindhunata, GP. (201.7). Ilange Semar. Katalog pameran. Yogyakarta: Bentara Budaya Yogyakarta.

Siswanto, N. (2019). Filosofi kepemimpinan Semar. Panggung, 29(3), 254-268.

DOI: http://dx.doi.org/10.267 42/panggung.v29i3.1011.

Sukmawati, R. A., \& Nesvihani, N. (2018).

Kemampuan Komunikasi Matematis dan Karakter Tanggung Jawab Siswa dalam Implementasi Model Pembelajaran Kooperatif Tipe Quick on The Draw di Kelas VIII. EDU-MAT: Jurnal Pendidikan Matematika, 6(1), 53-62.

DOI: http://dx.doi.org/10.205 27/edumat.v6i1.5120.

Whinarno, C., \& Arifin, B. (2019). Pesan dakwah dalam pementasan wayang kulit lakon "Ma'rifat Dewa Ruci" oleh dalang $\mathrm{Ki}$ Enthus Susmono. Jurnal Kopis: Kajian Penelitian dan 
Pemikiran Komunikasi

Penyiaran Islam, 2(1), 1-12.

Retrieved https://ejournal.iai-

tribakti.ac.id/index.php/kopis/a

rticle/view/1046/675. 